\title{
Implementation of international environmental standards in Russia (in terms of the provisions of the 1998 Aarhus Convention)
}

\author{
Olga Grigorieva ${ }^{1, *}$ \\ ${ }^{1}$ Moscow State Institute of International Relations, Moscow, Russia
}

\begin{abstract}
The study analyzes the prospects for Russia's ratification of the Aarhus Convention on Access to Information, Public Participation in Decision-Making and Access to Justice in Environmental Matters (1998). The analysis of federal legislation in the field of ecology is carried out.The emphasis is on the provisions that regulate the rights of citizens to access official information on the state of the environment, to participate in the discussion of environmental programs and projects; the right to judicial review of actions of authorities that violate such rights. On the example of the city of Moscow - a subject of the Russian Federation, the official electronic services and resources are shown that allow you to receive information about the state of the environment in real time. Such electronic resources have been created by the Moscow City Government and are available on all social networks. Based on the results of the study, the conclusion is substantiated that the existing legislation in Russia and the practice of its application generally comply with the standards of the Aarhus Convention. Its ratification will allow Russia to reach a qualitatively new level of international environmental standards.
\end{abstract}

\section{Introduction}

Sustainable development is the desire to achieve the necessary balance between the economy, meeting the needs of society and preserving the environment for future generations. It is based on the adoption of the necessary international standards and national legislation in the field of environmental protection, environmental monitoring, public awareness the 2030 Agenda for Sustainable Development was adopted by the UN General Assembly on September 25, 2015 [1]. In a truly democratic society, the authorities and the population actively interact on environmental issues. Publicity and transparency make available information about air pollution, reservoirs, government programs for the preservation of the environment. Problems of achieving goals and indicators of sustainable development are often discussed in the literature [2, 3].

International standards in this area are established by the Convention on Access to Information, Public Participation in Decision-Making and Access to Justice in Environmental Matters, which was adopted on June 25, 1998 in Denmark in the city of

\footnotetext{
*Corresponding author: 5618861@mail.ru
} 
Aarhus (hereinafter - the Aarhus Convention) [4]. Russia has signed but not ratified the Aarhus Convention. This article will examine legislation, government programs, electronic services in the field of ecology, which are developed in Russia. The possibility of public and business access to environmental information, public participation in decision-making will be shown. Ultimately, we will be able to understand Russia's readiness to ratify the Aarhus Convention.

\section{Materials and Methods}

The article analyzes the main provisions of the Aarhus Convention, which consolidate the very concept of "environmental information", define complete, reliable and timely information, sources, collection and dissemination of information, payment issues; mechanisms of public participation in the preparation and adoption of decisions, including the stages and methods of such participation; general questions about access to justice in environmental matters.

The information on the activities Aarhus Centers, which are located in 14 countries of the world, was used to facilitate the establishment of a dialogue between the public and the authorities on the availability of environmental information, decision-making and justice $[5]$.

The analysis of the Russian legislation on the environment is carried out. The Federal Law "On Environmental Protection" dated January 17, 2002 defines the foundations of state policy in the field of environmental protection for the preservation of biological diversity, natural resources, and ensuring environmental safety [6]. The Federal Law "On Environmental Expertise" dated 23.11.1995 establishes that this kind of expertise is aimed at preventing negative impact on the environment from human activities [7]. The national project "Ecology" should be implemented by December 31, 2024, involves work to fundamentally improve the environmental situation and the health of Russians [8].

A separate federal law on environmental information, on public access to environmental information, public participation of the population in the discussion of environmental issues in Russia is currently not adopted.

Regions - constituent entities of the Russian Federation play a significant role in regulating the distribution of environmental information. It is at the regional level that the corresponding electronic information resources have been developed and are freely available.

In this regard, the study was based on the official information of the Department of Nature Management and Environmental Protection of the city of Moscow. This regional executive body is in charge of environmental protection, rational nature management and environmental safety. The Department develops regulatory documents, the implementation of which is aimed at improving the state of the natural environment, implements citywide programs on ecology. The choice of the city of Moscow for an illustrative example in this study is not accidental. Moscow is a huge industrial metropolis with heavy and light industry enterprises, mechanical engineering and chemical industries. The uniqueness of the city in comparison with other megacities of the planet is that industrial enterprises are located within the city limits, often in the historical center of the city, adjacent to residential areas, parks, and reservoirs. The removal of industrial enterprises outside the city limits is practically unrealistic due to the congestion of urban transport highways. In addition, the territory of another subject of the Federation - the Moscow region - is immediately located within the city limits. In fact, the city of Moscow itself is located in the center of another region, a separate subject of the Federation, and does not have an "industrial suburb". This is clearly shown in the diagram [9]. 


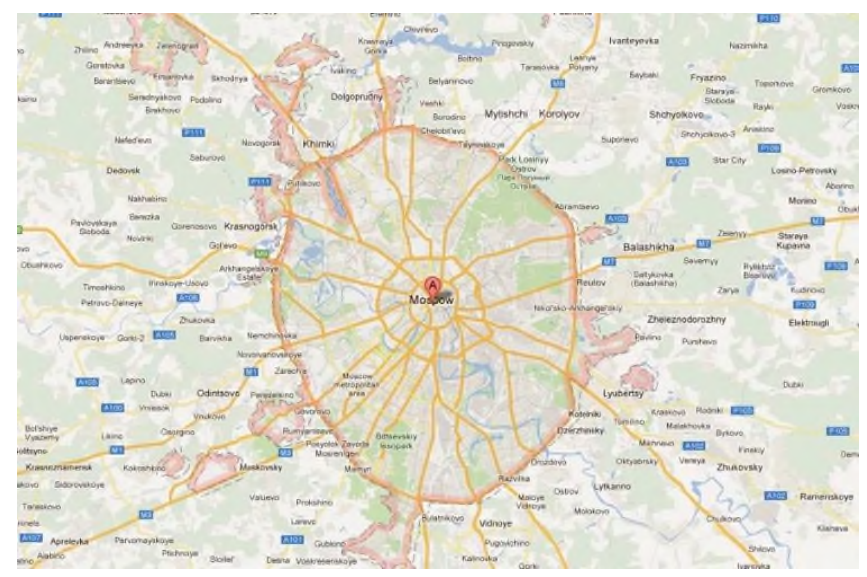

Fig. 1. Map of Moscow and the Moscow Region.

All industrial zones are located within the city limits of Moscow [10].

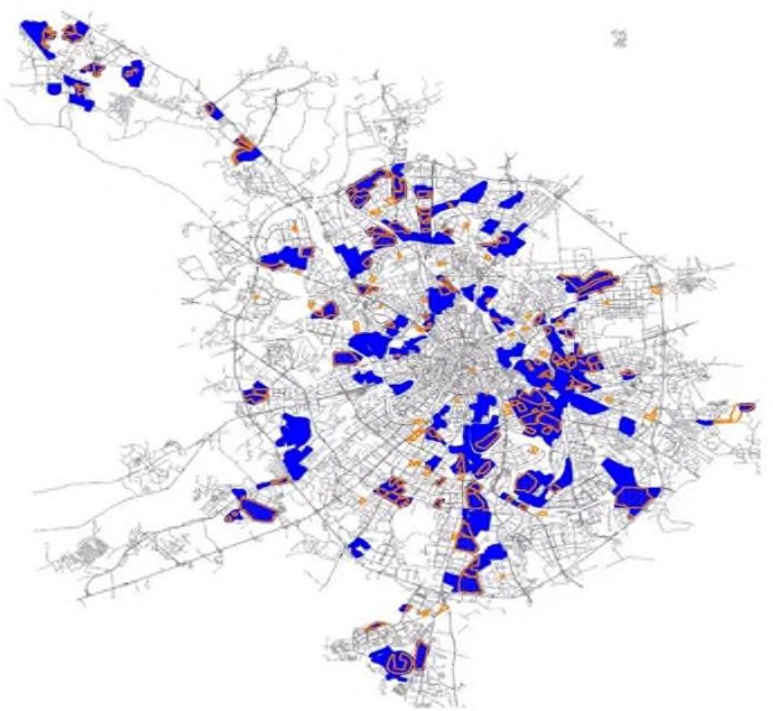

Fig. 2. Industrial zones of the city of Moscow.

Therefore, in relation to Moscow, we can only talk about the withdrawal of industrial enterprises from the central part of the city. Such a situation directly affects the state of the environment in the city, causes concern among the population, causes a constant need for environmental monitoring and availability of environmental information.

\section{Results}

The Aarhus Convention is an European one, but open for accession by any state. As noted on the OSCE official website: "The Aarhus Convention was adopted with the aim of strengthening the role of citizens and civil society organizations in addressing environmental issues and is based on the principles of participatory democracy. The Aarhus Convention establishes a number of rights of citizens and civil society organizations related to the environment. Parties to the Convention shall take the necessary measures to ensure 
that public authorities at the national, regional or local levels promote the effective realization of these rights". [11].

49 states have ratified the Aarhus Convention. These include almost all European countries, including the former Soviet republics [4].

Analysis of the text of the Aarhus Convention allows us to say that it regulates three large blocks of issues: 1) the right to receive official information from authorities about the state of the environment; 2) the right to public participation in the discussion of environmental programs and projects; 3 ) the right to access to justice in case of violation of the right to receive official environmental information and the right to participate in the adoption of environmental decisions and programs.

Koester V. this characterizes the compliance mechanism: "The compliance mechanism (CM), based solely on the article on compliance review, establishes a Compliance Committee (CC), constitutes the Committee and the MOP as the main bodies for review of compliance, and sets out in an annex the structure and function of the Committee as well as the procedures for reviewing compliance with the Convention". [12] Undoubtedly, these are the most important questions for every human on the planet. The right to a healthy environment, clean air and water, environmentally friendly production can be considered a natural right of every person. For many decades, industrial society has mercilessly exploited nature in an effort to create the most efficient industrial production. Until the very existence of humanity was threatened with extinction.

The adoption of the Aarhus Convention is a correct and timely step, which testifies to the concern of the world community about the state of the environment and its preservation for future generations. Ratification of the Convention presupposes that the states parties have brought their national environmental legislation in line with its provisions. We created not only a system for monitoring the state of the environment, but also the availability of information for the population, developed judicial procedures to protect the rights of citizens to access environmental information and participate in the discussion of state environmental programs.

Dellinger M. writes: "Large population segments around the globe are displeased with how their governments govern. This is no less so on the environmental stage. Calls for sustainable development and a greener economy are intense. At the same time, the speed with which Governments implement the provisions of the Convention is very slow" [13].

Russia signed, but has not yet ratified the Aarhus Convention. This issue is often discussed in publications. [14,15] Almost all authors agree that the Russian judicial system is not ready for a stream of complaints and lawsuits from citizens and businesses to protect environmental rights, which will follow the ratification.

The public and ecologists post on the Internet many photographs of the consequences of environmental disasters, individual cases of environmental damage. Here are just a few examples.

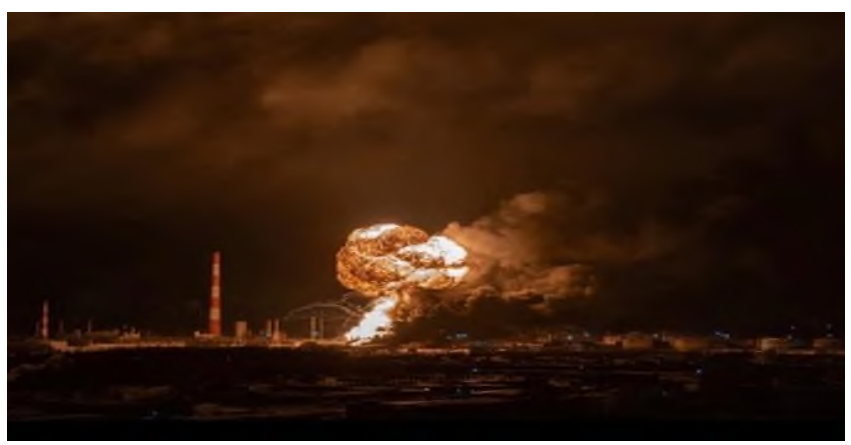

Fig. 3. The state of the atmospheric air. Ukhta city, Russia. 


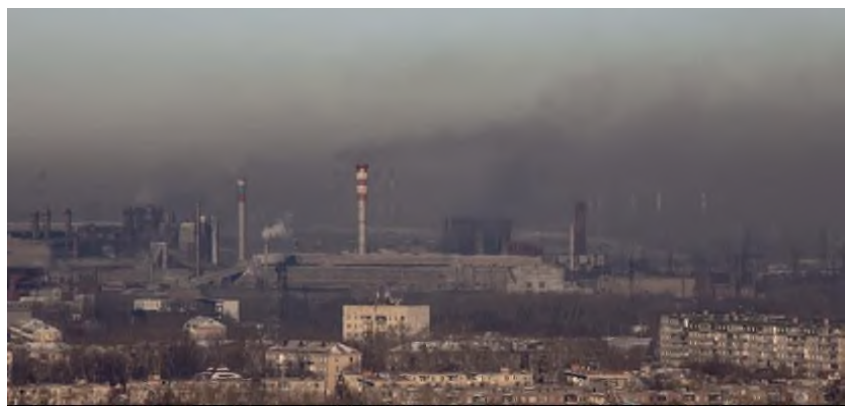

Fig. 4. The state of the atmospheric air. Chelyabinsk city, Russia.

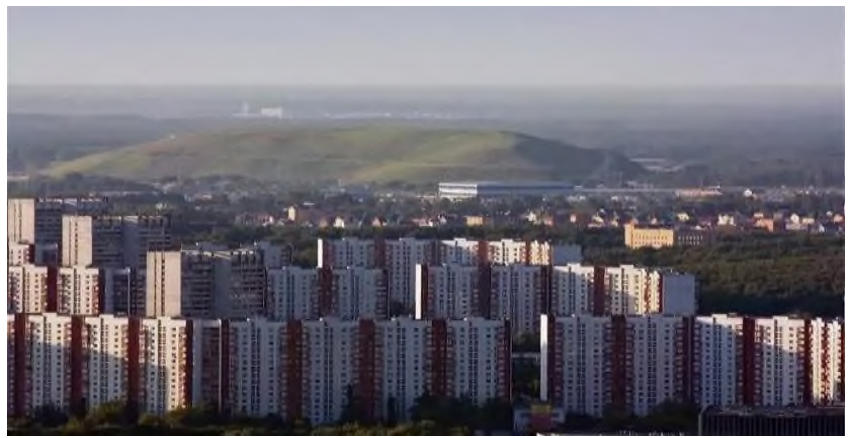

Fig. 5. The largest domestic waste landfill in Europe, Salaryevo district, Moscow, Russia. Today it is mothballed, adjacent to new residential areas.

Of course, citizens want to receive up-to-date information in real time on the state of the environment, on measures taken by the state to reduce harmful emissions into the atmosphere, wastewater emissions into water bodies, soil pollution, etc. Therefore, the ratification and implementation of the provisions of the Aarhus Convention in Russia is an urgent and urgent problem, dictated by the requirements of the times.

At the same time, it cannot be argued that Russia's environmental policy is at variance with world environmental standards. Russia systematically adopts laws in the field of ecology, which partly relate to public awareness of the state of the environment.

The Federal Law "On Environmental Protection" established the basic principles of environmental protection, including:

- the obligation to participate in environmental protection activities of government bodies of the Russian Federation, government bodies of the constituent entities of the Russian Federation, local government bodies, public associations and non-profit organizations, legal entities and individuals;

- observance of the right of everyone to receive reliable information about the state of the environment, as well as participation of citizens in decision-making regarding their rights to a favorable environment, in accordance with the legislation;

- organization and development of the environmental education system, education and formation of environmental culture;

- participation of citizens, public associations and non-profit organizations in solving problems of environmental protection (Article 3) [6].

Citizens are granted significant rights in the field of environmental protection (Article 11), including:

- the right to a favorable environment, to its protection from negative impacts caused by economic and other activities, natural and man-made emergencies, to reliable information about the state of the environment and to compensation for environmental damage; 
- the right to create public associations and other non-profit organizations carrying out activities in the field of environmental protection;

- the right to send appeals to state authorities, local authorities to obtain timely, complete and reliable information about the state of the environment in their places of residence, measures to protect it;

- the right to participate in meetings, rallies, demonstrations, processions and picketing, collecting signatures for petitions, referendums on environmental protection and other actions that do not contradict the legislation of the Russian Federation;

- the right to put forward proposals for the conduct of a public ecological expertise and participate in its implementation;

- the right to render assistance to the authorities in solving the issues of environmental protection;

- the right to apply to the authorities with complaints, statements and proposals on issues related to environmental protection, negative impact on the environment, and receive timely and reasonable answers; [6].

- the right to submit to the court claims for compensation for damage to the environment

It is not difficult to see that the above legal norms generally correspond to the provisions of the Aarhus Convention. And the mechanism existing in Russia for filing appeals to the authorities, complaints and claims to the courts makes it possible to very effectively implement these provisions of the Law in practice.

Another important act, which is generally consistent with the provisions of the Aarhus Convention, is the Federal Law "On Environmental Expertise". As stated in Article 1 of the Law, "environmental impact assessment is the establishment of compliance of documents and (or) documentation substantiating the planned economic and other activities in connection with the implementation of the environmental impact assessment object, environmental requirements established by technical regulations and legislation in the field of environmental protection, in order to preventing the negative impact of such activities on the environment." [7]

The public is also given a very wide range of rights regarding the environmental impact assessment. For instance:

- the right to put forward proposals for conducting a public environmental review of economic activities, the implementation of which affects the environmental interests of the population living in a given territory;

- the right to send reasoned proposals to the authority in writing on the environmental aspects of the planned economic activity;

- the right to receive information on the results of its implementation from the authorities organizing the state ecological expertise of specific objects of the ecological expertise. [7]

When preparing the conclusion of the state ecological expertise, the expert commission should consider materials reflecting public opinion.

\section{Discussion}

The examples considered allow us to judge that the existing environmental legislation in Russia complies with the standards adopted by the international community in the field of environmental information for citizens, participation of citizens in the discussion of environmental programs, and access to justice. That is, to those international standards that are enshrined in the Aarhus Convention.

However, the greatest debate is caused by the practice of informing the public about the state of the environment, the availability of such information in real time. As stated for the 
purpose of the study, the availability of environmental information to the population will be considered on the example of the city of Moscow. The Moscow City Government has established the Department of Nature Management and Environmental Protection. Since 2001, Moscow Environmental Monitoring has been subordinated to the Department. The main goal of its activities is the implementation of state environmental monitoring on the territory of the city of Moscow.

On the site, in real time on an interactive map, you can clearly see the state of the environment throughout the city, as well as the ecological situation at the current date and time. [16]
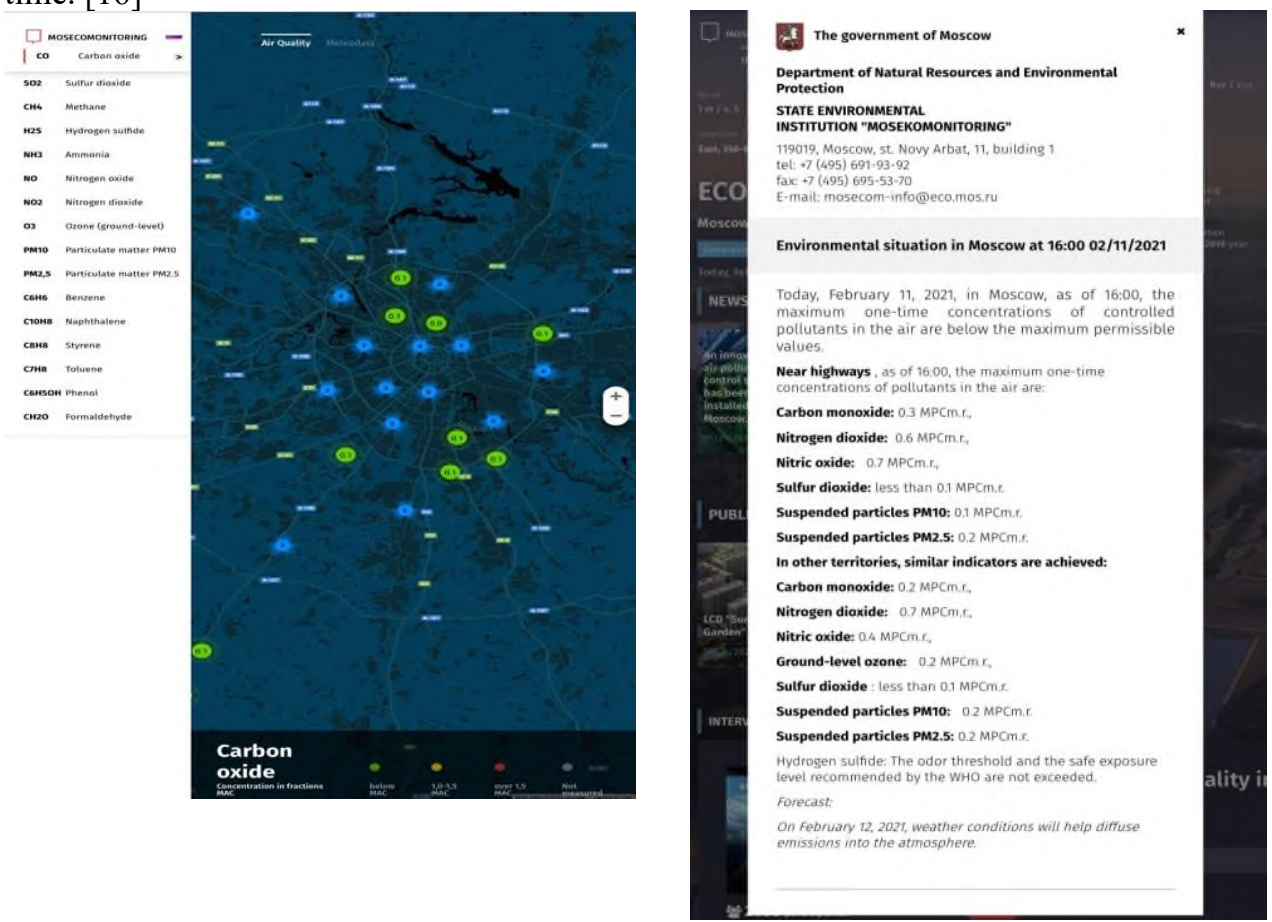

Fig. 6. Moscow Environmental Monitoring data on the environmental situation in the city in real time.

Moscow Ecological Monitoring data on the ecological situation in the city is available on all social networks. Special applications have been developed for smartphones of various operating systems.

\section{Conclusion}

Thus, both the current environmental legislation and the existing practice of informing the population about the state of the environment comply with the provisions of the Aarhus Convention. In Russia, at the legislative level, the right of citizens to receive official information from public authorities and local governments on the state of the environment is enshrined. The public can also actively participate in the discussion of environmental programs and projects that are planned and implemented by the authorities. Participate in public hearings on environmental issues. The right to access to justice in order to appeal against illegal actions and inaction, decisions of authorities and officials, if they violate the rights and legitimate interests of citizens, has been secured. Consequently, citizens can 
appeal in court against violations of the right to receive official environmental information and the right to participate in environmental decisions and programs.

The research conducted allows us to judge that at present Russia is ready to ratify the Aarhus Convention. If this is followed by a stream of complaints and petitions to the courts, it is possible that this will push the state towards more effective measures to protect the environment.

\section{References}

1. United Nations (UN), Transforming our world: The 2030 agenda for sustainable development. Resolution adopted by the General Assembly on 25 September 2015. $\mathrm{A} / \mathrm{RES} / 70 / 1$. http://www.un.org/ga/search/view_doc.asp?symbol=A/RES/70/1\&Lang=E

2. R. Levett, Sustainability indicators: Integrating quality of life and environmental protection. Journal of the Royal Statistical Society 161(3), 291-302 (1998)

3. D. Le Blanc, Towards integration at last? The Sustainable Development Goals as a network of targets, UN department of economic and social affairs, Sustainable Development 23(3), 176-187 (2015)

4. Convention on Access to Information, Public Participation in Decision-Making and Access to Justice in Environmental Matters [Aarhus Convention]. https://www.un.org/ru/documents/decl_conv/conventions/orhus.shtml

5. Aarhus Centres. https://aarhus.osce.org/

6. Federal law of the Russian Federation "On Environmental Protection" (January, 17, 2002, №. 7) Moscow, Russia.

7. Federal law of the Russian Federation "On Environmental expertise" (November, 23, 1995, №. 174) Moscow, Russia.

8. National project, https://ecologyofrussia.ru/proekt/

9. Map of Moscow, http://moskva-map.ru/eng.htm

10. "Moscow-City": high prospects, https://m.archsovet.msk.ru/article/aktualno/moskvasiti-vysokie-perspektivy

11. Aarhus Convention, https://aarhus.osce.org/ru/node/12

12. V. Koester, The Compliance Committee of the Aarhus Convention (An Overview of Procedures and Jurisprudence). Environmental. Policy and Law 37 (2007)

13. M. Dellinger, The years of the Aarhus Convention: how procedural democracy is paving the way for substantive change in national and international environmental Law. Environmental. Policy and Law 309 (2012)

14. I.P. Dudykina, Aarhus Convention: Russian and foreign doctrinal assessments. Moscow Journal of International Law 4, 96-109 (2018)

15. E. Makritskaya, The right to access environmental information in the paradigm of the Aarhus Convention: experience in implementation in certain states. Siberian Legal Bulletin 4(91), 116-119 (2020)

16. Moscow Environmental Monitoring, https://mosecom.mos.ru 